Article

\title{
Polystyrene Chain Growth Initiated from Dialkylzinc for Synthesis of Polyolefin-Polystyrene Block Copolymers
}

Tae Jin Kim, Jun Won Baek, Seung Hyun Moon, Hyun Ju Lee, Kyung Lee Park, Sung Moon Bae, Jong Chul Lee, Pyung Cheon Lee and Bun Yeoul Lee *(D)

Department of Molecular Science and Technology, Ajou University, Suwon 443-749, Korea; playing3457@ajou.ac.kr (T.J.K.); btw91@ajou.ac.kr (J.W.B.); freethemoon@ajou.ac.kr (S.H.M.); hjulee4639@ajou.ac.kr (H.J.L.); rudf193@ajou.ac.kr (K.L.P.); bsm1029@ajou.ac.kr (S.M.B.); leejc@ajou.ac.kr (J.C.L.); pclee@ajou.ac.kr (P.C.L.)

* Correspondence: bunyeoul@ajou.ac.kr; Tel.: +82-31-219-1844

Received: 4 January 2020; Accepted: 16 January 2020; Published: 2 March 2020

\begin{abstract}
Polyolefins (POs) are the most abundant polymers. However, synthesis of PO-based block copolymers has only rarely been achieved. We aimed to synthesize various PO-based block copolymers by coordinative chain transfer polymerization (CCTP) followed by anionic polymerization in one-pot via conversion of the CCTP product (polyolefinyl) ${ }_{2} \mathrm{Zn}$ to polyolefinyl-Li. The addition of 2 equiv $t$-BuLi to (1-octyl) ${ }_{2} \mathrm{Zn}$ (a model compound of (polyolefinyl) ${ }_{2} \mathrm{Zn}$ ) and selective removal or decomposition of $(t \mathrm{Bu})_{2} \mathrm{Zn}$ by evacuation or heating at $130{ }^{\circ} \mathrm{C}$ afforded 1-octyl-Li. Attempts to convert (polyolefinyl) ${ }_{2} \mathrm{Zn}$ to polyolefinyl-Li were unsuccessful. However, polystyrene (PS) chains were efficiently grown from (polyolefinyl) ${ }_{2} \mathrm{Zn}$; the addition of styrene monomers after treatment with $t$-BuLi and pentamethyldiethylenetriamine (PMDTA) in the presence of residual olefin monomers afforded PO-block-PSs. Organolithium species that might be generated in the pot of $t$-BuLi, PMDTA, and olefin monomers, i.e., [ $\mathrm{Me}_{2} \mathrm{NCH}_{2} \mathrm{CH}_{2} \mathrm{~N}(\mathrm{Me}) \mathrm{CH}_{2} \mathrm{CH}_{2} \mathrm{~N}(\mathrm{Me}) \mathrm{CH}_{2} \mathrm{Li}, \mathrm{Me}_{2} \mathrm{NCH}_{2} \mathrm{CH}_{2} \mathrm{~N}(\mathrm{Me}) \mathrm{Li}$ (PMDTA), pentylallyl-Li.(PMDTA)], as well as PhLi.(PMDTA), were screened as initiators to grow PS chains from (1-hexyl) ${ }_{2} \mathrm{Zn}$, as well as from (polyolefinyl) ${ }_{2} \mathrm{Zn}$. Pentylallyl-Li.(PMDTA) was the best initiator. The $M_{\mathrm{n}}$ values increased substantially after the styrene polymerization with some generation of homo-PSs (27-29\%). The $M_{\mathrm{n}}$ values of the extracted homo-PS suggested that PS chains were grown mainly from polyolefinyl groups in [(polyolefinyl $)_{2}$ (pentylallyl)Zn] $]^{-}[\mathrm{Li} \cdot(\mathrm{PMDTA})]^{+}$formed by pentylallyl-Li.(PMDTA) acting onto (polyolefinyl) ${ }_{2} \mathrm{Zn}$.
\end{abstract}

Keywords: polyolefin; polystyrene; block copolymer; coordinative chain transfer polymerization; initiator; organolithium; dialkylzinc

\section{Introduction}

The synthesis of block copolymers has been a topical issue in the field of polymer science and chemistry [1]. Conventionally, block copolymers are synthesized by controlled living anionic or radical polymerizations [2,3]. A typical example is polystyrene-block-polybutadiene-block-polystyrene (SBS), which is industrially produced by controlled living anionic polymerization at a large scale. Polyolefins (POs) are the most abundant polymers, produced with ethylene and $\alpha$-olefins, at a scale of more than 120 million metric tons per year worldwide. However, PO-based block copolymers have rarely been synthesized because $\alpha$-olefins cannot be polymerized by either anionic or radical initiators [4-6]. The lack of versatile synthetic tools has promoted the development of multistep routes for the syntheses of PO-based block copolymers [7-15]. For example, polystyrene-block-poly(ethylene-co-1-butene)-block-polystyrene is produced industrially via a two-step 
process: Controlled living anionic polymerization of styrene and butadiene, and subsequent hydrogenation of the resulting SBS [16].

POs are mainly produced by coordination polymerization with transition-metal-based catalysts. Catalysts that can polymerize ethylene, $\alpha$-olefins, or both, in a controlled living fashion, enable the synthesis of olefin block copolymers (OBCs). However, these copolymers are composed of solely PO chains with a varying ethylene/ $\alpha$-olefin composition [17-19]. An intrinsic drawback of this method is the growth of only one polymer chain per catalyst site, i.e., [PO chains]/[catalyst] $=1$. A practical method for the industrial production of OBCs is based on coordinative chain transfer polymerization (CCTP). In CCTP, a transition-metal-based catalyst (e.g., 1 in Scheme 1 ) that can polymerize ethylene, $\alpha$-olefins, or both in a controlled living fashion is used with a chain transfer agent (CTA, e.g., $\mathrm{Et}_{2} \mathrm{Zn}$ ) in excess relative to the catalyst (e.g., [ $\mathrm{Zn}] /[\mathrm{Hf}]>100)$. In CCTP, $\mathrm{PO}$ chains are grown uniformly and progressively from all the fed CTAs via rapid alkyl exchange between the zinc sites and the chain-growing catalyst sites $[20,21]$. Therefore, it is possible to grow $\mathrm{PO}$ chains with a varying ethylene/ $\alpha$-olefin composition either, by the sequential variation of ethylene/ $\alpha$-olefin feed ratio or by employing a dual catalytic system with distinctly different monomer reactivities. Thus, we can successfully produce diblock and multiblock copolymers composed of hard crystalline, and soft rubbery PO blocks [22-26].
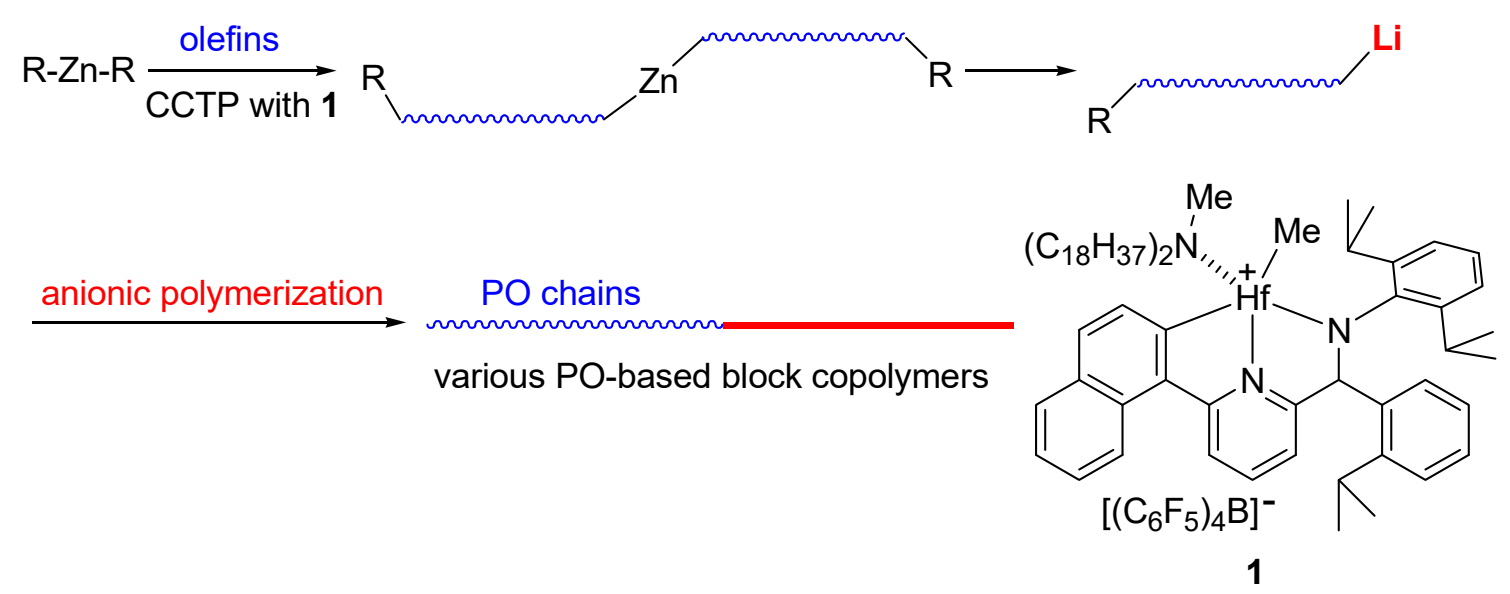

Scheme 1. Synthetic scheme for various polyolefin-based block copolymers.

(Polyolefinyl $)_{2} \mathrm{Zn}$ results from CCTP and is usually quenched with acid to destroy the Zn-C bonds. The further growth of polymer chains initiating from (polyolefinyl) ${ }_{2} \mathrm{Zn}$ may be useful for the syntheses of PO-based block copolymers [27]. Syntheses of polyethylene-block-polyester and polyethylene-block-polyether have been attempted with $\mathrm{POs}$ functionalized with -OH end groups, which were generated by treatment of the CCTP product (polyolefinyl) ${ }_{2} \mathrm{Zn}$ with $\mathrm{O}_{2}$ [28-31]. We also discovered a method to grow polystyrene (PS) chains initiating from (polyolefinyl) ${ }_{2} \mathrm{Zn}$ that allows the syntheses of commercially more relevant PO-block-PS and PS-block-PO-block-PS in one-pot [32-35]. In those works, $n$-BuLi-(TMEDA) (TMEDA $=$ tetramethylethylenediamine, i.e., $\mathrm{Me}_{2} \mathrm{NCH}_{2} \mathrm{CH}_{2} \mathrm{NMe}_{2}$ ) and $\mathrm{Me}_{3} \mathrm{SiCH}_{2} \mathrm{Li}$.(PMDTA) (PMDTA = pentamethyldiethylenetriamine, i.e., $\mathrm{Me}_{2} \mathrm{NCH}_{2} \mathrm{CH}_{2} \mathrm{~N}(\mathrm{Me}) \mathrm{CH}_{2} \mathrm{CH}_{2} \mathrm{NMe}_{2}$ ) were introduced to grow PS chains from (polyolefinyl) ${ }_{2} \mathrm{Zn}$. In this work, we pursued a more efficient method for PS chain growth from (polyolefinyl) ${ }_{2} \mathrm{Zn}$ with an additional aim to expand the scope of the chains that can be grown from (polyolefinyl) ${ }_{2} \mathrm{Zn}$ (Scheme 1). Recently, syntheses of functionalized POs are a topical issue [36-38].

\section{Materials and Methods}

All manipulations were performed under an inert atmosphere using a standard glove box and Schlenk techniques. Methylcyclohexane was purchased from Sigma-Aldrich and purified over $\mathrm{Na} / \mathrm{K}$ alloy. The ethylene/propylene mixed gas was purified over trioctylaluminum $(0.6 \mathrm{M}$ in methylcyclohexane) in a bomb reactor $(2.0 \mathrm{~L}) .{ }^{1} \mathrm{H}$ NMR $(600 \mathrm{MHz})$ and ${ }^{13} \mathrm{C}$ NMR $(150 \mathrm{MHz})$ spectra 
were recorded on a JEOL ECZ600 instrument. The gel permeation chromatography (GPC) data were obtained in 1,2,4-trichlorobenzene at $160{ }^{\circ} \mathrm{C}$ using a PL-GPC 220 system equipped with an RI detector and two columns [PLgel mixed-B $7.5 \times 300 \mathrm{~mm}$ from Varian (Polymer Lab)]. (1-Octyl) ${ }_{2} \mathrm{Zn}$ and (1-hexyl $)_{2} \mathrm{Zn}$ were prepared and purified as described in the literature [26]. n-BuLi and sec-BuLi were used as neat oils, while $t$-BuLi as solid after removing the solvent inside the glove box.

Conversion of (1-octyl) ${ }_{2} \mathrm{Zn}$ to (1-octyl)Li. (1-Octyl) $2 \mathrm{Zn}(58.4 \mathrm{mg}, 0.200 \mathrm{mmol})$ was added to a solution of $t$ - $\mathrm{BuLi}(25.6 \mathrm{mg}, 0.400 \mathrm{mmol})$ in methylcyclohexane $(27.0 \mathrm{~g})$. After stirring for $15 \mathrm{~min}$ at room temperature, volatiles were removed using a vacuum line. A light-yellow oil was obtained, of which the ${ }^{1} \mathrm{H}$ and ${ }^{13} \mathrm{C}$ NMR spectra agreed with those of 1 -octyllithium. Differently, (1-octyl) $2 \mathrm{Zn}(0.29 \mathrm{~g}$, $1.0 \mathrm{mmol})$ was added to a solution of $t$-BuLi $(0.13 \mathrm{~g}, 2.0 \mathrm{mmol})$ in decane $(10 \mathrm{~g})$. The solution was stirred for $20 \mathrm{~min}$ at $130{ }^{\circ} \mathrm{C}$ while venting off the generated gases. A black solid was generated, which was filtered through Celite. Decane was distilled at $50{ }^{\circ} \mathrm{C}$ under full vacuum to obtain a light-yellow oil of which the ${ }^{1} \mathrm{H}$ and ${ }^{13} \mathrm{C}$ NMR spectra agreed with those of 1 -octyllithium $(0.22 \mathrm{~g}, 91 \%) .{ }^{1} \mathrm{H} \mathrm{NMR}\left(\mathrm{C}_{6} \mathrm{D}_{6}\right)$ : $\delta 1.54\left(\mathrm{~s}, 2 \mathrm{H}, \mathrm{CH}_{2}\right), 1.49-1.30\left(\mathrm{br}, 10 \mathrm{H}, \mathrm{CH}_{2}\right), 0.94\left(\mathrm{t}, J=7.2 \mathrm{~Hz}, 3 \mathrm{H}, \mathrm{CH}_{3}\right), 0.33\left(\mathrm{~s}, 2 \mathrm{H}, \mathrm{LiCH}_{2}\right) \mathrm{ppm}$. ${ }^{13} \mathrm{C}$ NMR $\left(\mathrm{C}_{6} \mathrm{D}_{6}\right): \delta 38.79,32.50,32.23,29.94,29.79,29.68,23.20,14.43$ ppm.

1-Octene, $\boldsymbol{n}$-BuLi, and PMDTA in methylcyclohexane. $n$-BuLi $(1.10 \mathrm{~g}, 17.3 \mathrm{mmol})$ was added dropwise to a solution containing PMDTA (3.00 g, $17.3 \mathrm{mmol})$ and 1-octene $(3.90 \mathrm{~g}, 34.6 \mathrm{mmol})$ in methylcyclohexane (77 g). After stirring overnight at room temperature, the yellowish solution (2.16 mmol-Li/g) was used for the styrene polymerizations.

$\mathbf{M e}_{2} \mathbf{N C H}_{2} \mathrm{CH}_{2} \mathbf{N}(\mathrm{Me}) \mathrm{CH}_{2} \mathrm{CH}_{2} \mathbf{N}(\mathrm{Me}) \mathrm{CH}_{2} \mathrm{Li}$. sec-BuLi (12.8 mg, $\left.0.200 \mathrm{mmol}\right)$ was added dropwise to a solution of PMDTA $(34.6 \mathrm{mg}, 0.200 \mathrm{mmol})$ in methylcyclohexane $(1.50 \mathrm{~g})$. After stirring for $30 \mathrm{~min}$ at room temperature, the solution $(0.129 \mathrm{mmol}-\mathrm{Li} / \mathrm{g})$ was used for the styrene polymerizations. Additionally, sec-BuLi (12.8 mg, $0.200 \mathrm{mmol})$ and PMDTA (34.6 mg, $0.200 \mathrm{mmol})$ were dissolved in $\mathrm{C}_{6} \mathrm{D}_{12}(\sim 0.5 \mathrm{~mL})$ and an ${ }^{1} \mathrm{H}$ NMR spectrum was recorded after $30 \mathrm{~min}$.

$\mathbf{M e}_{2} \mathbf{N C H}_{2} \mathbf{C H}_{2} \mathbf{N}(\mathrm{Me}) \mathrm{Li}$. $n$-BuLi $(10 \mathrm{~mL}, 1.65 \mathrm{M}, 16.5 \mathrm{mmol})$ was added dropwise to a solution of $\mathrm{Me}_{2} \mathrm{NCH}_{2} \mathrm{CH}_{2} \mathrm{~N}(\mathrm{Me}) \mathrm{H}(1.69 \mathrm{~g}, 16.5 \mathrm{mmol})$ in hexane $(25 \mathrm{~mL})$. After stirring for $5 \mathrm{~h}$ at room temperature, the resulting solution was filtered through Celite. The solvent was removed using a vacuum line, and we obtained a white solid $(1.56 \mathrm{~g}, 88 \%)$ that was used for styrene polymerizations after adding it to an equivalent amount of PMDTA in methylcyclohexane. ${ }^{1} \mathrm{H}$ NMR $\left(\mathrm{C}_{6} \mathrm{D}_{6}\right): \delta 3.21\left(\mathrm{br}, 2 \mathrm{H}, \mathrm{CH}_{2}\right)$, 3.11 (br, 3H, NLi $\left.\left(\mathrm{CH}_{3}\right)\right), 2.45$ (br, 2H, $\left.\mathrm{CH}_{2}\right), 1.98$ (br, 6H, $\left.\mathrm{N}\left(\mathrm{CH}_{3}\right)_{2}\right)$ ppm.

Pentylallyl-Li-(PMDTA). n-BuLi (0.14 mg, $2.2 \mathrm{mmol})$ was added dropwise to PMDTA (0.37 g, $2.2 \mathrm{mmol})$ in 1-octene $(13.0 \mathrm{~g})$. After stirring overnight at room temperature, the yellowish solution $(0.16 \mathrm{mmol}-\mathrm{Li} / \mathrm{g})$ was used for the styrene polymerizations. An aliquot was analyzed with ${ }^{1} \mathrm{H} \mathrm{NMR}$ spectroscopy. After recording the ${ }^{1} \mathrm{H}$ NMR spectrum, the solution in $\mathrm{C}_{6} \mathrm{D}_{6}$ was quenched with $\mathrm{H}_{2} \mathrm{O}$ (or $\mathrm{D}_{2} \mathrm{O}$ ) and filtered over a short pad of anhydrous $\mathrm{MgSO}_{4}$ in a pipette to re-record an ${ }^{1} \mathrm{H}$ NMR spectrum.

PhLi-(PMDTA). $n$-BuLi (12.8 mg, $0.200 \mathrm{mmol})$ was added dropwise to a solution of PMDTA $(34.6 \mathrm{mg}, 0.200 \mathrm{mmol})$ in $\mathrm{C}_{6} \mathrm{D}_{6}(0.600 \mathrm{~g})$. After stirring for $30 \mathrm{~min}$ at room temperature, the solution (0.31 mmol-Li/g) was analyzed with ${ }^{1} \mathrm{H}$ NMR spectroscopy and used for the styrene polymerizations.

PS chain growth from (1-hexyl) $2 \mathrm{Zn}$. Pentylallyl-Li·(PMDTA) $(96 \mu \mathrm{mol})$ was added to a flask containing (1-hexyl) $2 \mathrm{Zn}(22.6 \mathrm{mg}, 96 \mu \mathrm{mol})$ and methylcyclohexane $(27 \mathrm{~g})$ inside a glove box. Styrene $(5.0 \mathrm{~g}, 48.0 \mathrm{mmol})$ was added, and the anionic polymerization was performed at $90{ }^{\circ} \mathrm{C}$ for $5 \mathrm{~h}$. Then, aqueous $\mathrm{HCl}(2 \mathrm{~N}, 0.3 \mathrm{~mL})$ was added, and the resulting solution was stirred for $30 \mathrm{~min}$ at $90^{\circ} \mathrm{C}$ to destroy the zinc species. The solution was filtered through a short pad of silica gel, which was subsequently washed with toluene. In order to isolate PS, toluene was removed with a rotary evaporator; the isolated sample was dried in a vacuum oven at $130{ }^{\circ} \mathrm{C}$ for $5 \mathrm{~h}(5.00 \mathrm{~g}, 100 \%)$.

Synthesis of poly(ethylene-co-propylene)- $\boldsymbol{b}$-PS. A bomb reactor $(125 \mathrm{~mL})$ was evacuated at $60{ }^{\circ} \mathrm{C}$ for $1 \mathrm{~h}$. After filling the reactor with ethylene gas at atmospheric pressure, a solution of $\mathrm{Me}_{3} \mathrm{Al}(29.0 \mathrm{mg}$, $200 \mu \mathrm{mol}-\mathrm{Al})$ in methylcyclohexane $\left(15.5 \mathrm{~g}\right.$ ) was added. The mixture was stirred for $40 \mathrm{~min}$ at $100{ }^{\circ} \mathrm{C}$ using a mantle, and the solution was subsequently removed using a cannula. The reactor was evacuated again to remove any residual solvent, and it was filled with ethylene/propylene gas at atmospheric 
pressure. This washing procedure was performed to remove any catalyst poisons. The reactor was charged with methylcyclohexane (15.5 g) containing MMAO (modified-methylaluminoxane, AkzoNobel, $6.7 \mathrm{wt} \%$-Al in heptane, $20 \mathrm{mg}, 50 \mu \mathrm{mol}-\mathrm{Al}$ ) and the temperature was set to $80^{\circ} \mathrm{C}$. A solution of (1-hexyl) ${ }_{2} \mathrm{Zn}(35.4 \mathrm{mg}, 150 \mu \mathrm{mol}-\mathrm{Zn})$ in methylcyclohexane $(10.0 \mathrm{~g})$ and a solution of $\mathbf{1}$ in cyclohexane $(8.7 \mu \mathrm{mol} / \mathrm{g}, 230 \mathrm{mg}, 2.0 \mu \mathrm{mol})$ diluted with methylcyclohexane $(0.5 \mathrm{~g})$ were successively injected. An ethylene/propylene mixed gas (10 bar/15 bar, total 25 bar) was charged from a tank into the reactor at $25 \mathrm{bar}$, and the mixture was polymerized for $40 \mathrm{~min}$. The temperature increased spontaneously to $110{ }^{\circ} \mathrm{C}$ within $5 \mathrm{~min}$ and was subsequently maintained at $90-100^{\circ} \mathrm{C}$ with a controller. The pressure in the tank decreased from 23 to 21 bar. After the remaining ethylene/propylene mixed gas was vented off, an aliquot was taken for a GPC study. Pentylallyl-Li.(PMDTA) $(200 \mu \mathrm{mol})$ in methylcyclohexane $(10.0 \mathrm{~g})$ was injected at $95{ }^{\circ} \mathrm{C}$. After stirring for $15 \mathrm{~min}$ at $95{ }^{\circ} \mathrm{C}$, a solution of styrene $(5.0 \mathrm{~g})$ in methylcyclohexane $(5.0 \mathrm{~g})$ was injected, and the mixture was polymerized for $4 \mathrm{~h}$ while controlling the temperature within the range of $90-100{ }^{\circ} \mathrm{C}$. An aliquot was taken for ${ }^{1} \mathrm{H}$ NMR spectroscopy; the spectrum showed no signals due to the styrene monomer. Acetic acid $(2.0 \mathrm{~mL})$ and ethanol $(30 \mathrm{~mL})$ were successively injected into the reactor. The generated polymer was dried in a vacuum oven at $160{ }^{\circ} \mathrm{C}(18.1 \mathrm{~g})$. After dissolving the polymer $(3.0 \mathrm{~g})$ in chloroform $(30 \mathrm{~g})$ at $60^{\circ} \mathrm{C}$ for $3 \mathrm{~h}$, acetone $(60 \mathrm{~g})$ was added to precipitate the PO-block-PS. Homo-PS, which is soluble in chloroform/acetone mixed solvents, was isolated by filtration.

\section{Results and Discussion}

\subsection{Converting Dialkylzinc to Alkyllithium}

Alkyllithium is a very reactive species commonly used in living anionic polymerizations as an initiator. A developed method to convert dialkylzinc to alkyllithium would be a powerful tool for the syntheses of various types of PO-based block copolymers (Scheme 1) [39]. Alkyllithium is a more reactive species than the corresponding dialkylzinc, and the reaction for converting alkyllithium to dialkylzinc is conventionally adopted, whereas its reverse reaction, i.e., converting dialkylzinc to alkyllithium is not favored and not yet realized. We expected that the addition of very reactive and bulky $t$-BuLi (2.0 eq) to dialkylzinc (e.g., (1-octyl) ${ }_{2} \mathrm{Zn}$ ) might transiently generate 1-octyllithium and $(t \mathrm{Bu})_{2} \mathrm{Zn}$ and that the generated $(t \mathrm{Bu})_{2} \mathrm{Zn}$ might be selectively removed from the reaction pot through evacuation or decomposition at a high temperature (Scheme 2$)$. The removal of volatiles under full vacuum from a flask containing (1-octyl $)_{2} \mathrm{Zn}$ and $t$-BuLi in methylcyclohexane yielded 1-octyllithium in $91 \%$ yield. In the ${ }^{1} \mathrm{H}$ NMR spectrum of the remaining, we observed a set of signals that was assigned to 1-octyllithium, especially by comparison with the signals of the commercial source of 1-hexyllithium (Figure 1, and Figure $\mathrm{S} 1$ for ${ }^{13} \mathrm{C}$ NMR spectrum). The use of bulky $t$-BuLi was essential for the successful conversion of (1-octyl) $2 \mathrm{Zn}$ to 1-octyllithium; when $n-\mathrm{BuLi}$, sec-BuLi, or $\mathrm{Me}_{3} \mathrm{SiCH}_{2} \mathrm{Li}$ were used instead of $t$-BuLi, only a mixture of alkyllithium and (1-octyl $)_{2} \mathrm{Zn}$ remained after evacuation, and not 1-octyllithium.

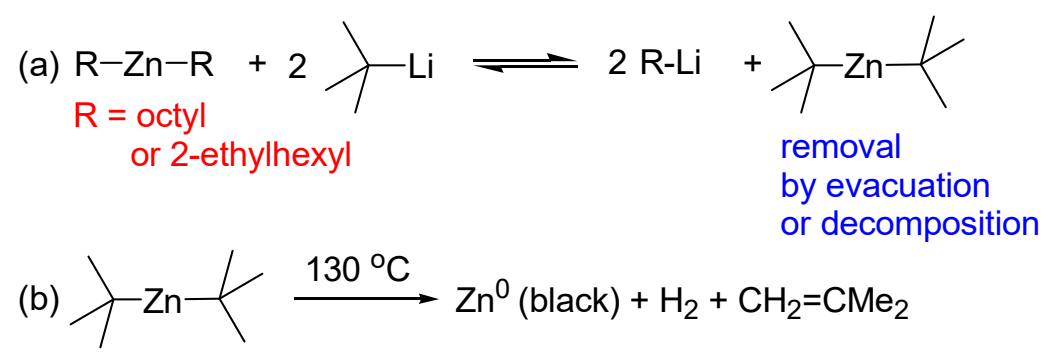

Scheme 2. Converting $\mathrm{R}_{2} \mathrm{Zn}$ to RLi. 


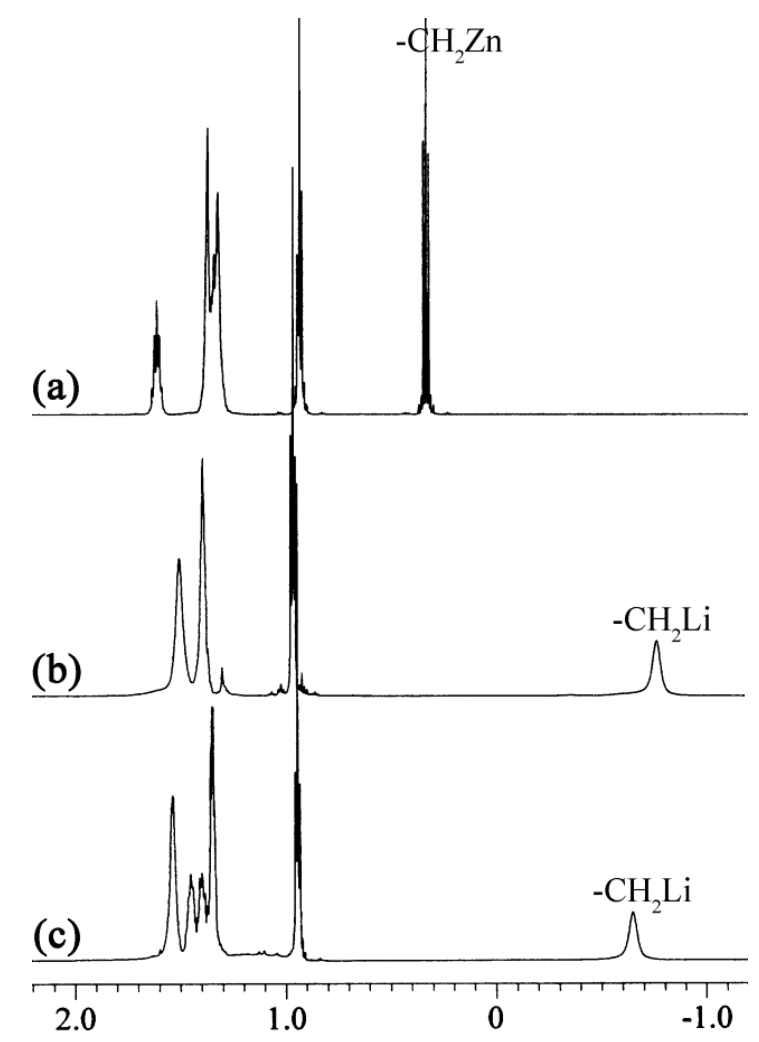

Figure 1. ${ }^{1} \mathrm{H}$ NMR spectra of: (a) (1-Octyl) ${ }_{2} \mathrm{Zn}$; (b) Commercial source of 1-hexyllithium; (c) 1-Octyllithium generated from (1-octyl $)_{2} \mathrm{Zn}$.

The transiently generated $(t \mathrm{Bu})_{2} \mathrm{Zn}$ could also be removed via selective decomposition at a high temperature of $130^{\circ} \mathrm{C}$. (Primary alkyl) ${ }_{2} \mathrm{Zn}$ compounds (e.g., $\mathrm{Et}_{2} \mathrm{Zn}$ and (1-octyl) $)_{2} \mathrm{Zn}$ ) are stable up to $150{ }^{\circ} \mathrm{C}$ and can be readily used in CCTP as CTAs at high temperatures of $125-140{ }^{\circ} \mathrm{C}$ [23]. In contrast, we found that $(t \mathrm{Bu})_{2} \mathrm{Zn}$ was decomposed at $130{ }^{\circ} \mathrm{C}$, and a black solid precipitated when a solution of $(t \mathrm{Bu})_{2} \mathrm{Zn}$ in decane was heated at $130{ }^{\circ} \mathrm{C}$. Isobutene and $\mathrm{H}_{2}$ signals were detected in the ${ }^{1} \mathrm{H}$ NMR spectrum when the reaction was performed in a sealed tube in toluene- $\mathrm{d}_{8}$ (Scheme $2 \mathrm{~b}$ ). (Primary alkyl)lithium, e.g., $n$-BuLi, was negligibly decomposed in decane at $130{ }^{\circ} \mathrm{C}$ (half-life, $6 \mathrm{~h}$ ) [40]. We found that $t$-BuLi was also persistent at $130^{\circ} \mathrm{C}$ for a short time of $\sim 30 \mathrm{~min}$. Accordingly, when a solution of (1-octyl) $)_{2} \mathrm{Zn}$ and $t$-BuLi (2.0 eq) in decane was heated at $130{ }^{\circ} \mathrm{C}$ for $30 \mathrm{~min}$, a black solid precipitated, which was indicative of the decomposition of $(t \mathrm{Bu})_{2} \mathrm{Zn}$; 1-octyllithium was cleanly isolated from the reaction pot by filtration in $91 \%$ yield. When benzaldehyde was added after the thermal treatment, $\mathrm{PhCH}(\mathrm{OH})\left(\mathrm{CH}_{2}\right)_{7} \mathrm{CH}_{3}$ was afforded, which additionally supported the successful generation of 1-octyllithium; (1-octyl $)_{2} \mathrm{Zn}$ does not react with benzaldehyde. Employing the same method, (2-ethylhexyl) ${ }_{2} \mathrm{Zn}$ was also converted to 2-ethylhexyl-Li in high yield (84\%; Figure S2).

\subsection{Attempts to Synthesize Block Copolymers}

(Polyolefinyl) ${ }_{2} \mathrm{Zn}$ was prepared via coordinative chain transfer copolymerizations (CCTcoPs) performed using a pyridylamidohafnium catalyst (1 in Scheme 1) in methylcyclohexane at high temperatures of $90-110{ }^{\circ} \mathrm{C}$ by feeding ethylene/propylene mixed gases. Catalyst $\mathbf{1}$ is the best in performing CCTcoPs [22,33,41-43]. It undergoes fast alkyl exchange with Zn sites to generate PO chains with a narrow molecular weight distribution [21,44]. The $\beta$-elimination process can be avoided with $\mathbf{1}$, preventing the generation of PO chains that are not attached to $\mathrm{Zn}$ sites $[18,45,46]$. Moreover, $\mathbf{1}$ is capable of incorporating a significant amount of $\alpha$-olefins in an ethylene/ $\alpha$-olefin copolymerization [47]. A minimal amount of MMAO (50 $\mu$ mol-Al) had to be fed, in addition to the CTA (1-hexyl) ${ }_{2} \mathrm{Zn}$ (100 or $200 \mu \mathrm{mol}-\mathrm{Al})$, to realize the full activity of $\mathbf{1}$, even though PO chain growth from some Al-sites was 
unavoidable $[26,48,49]$. The generated (polyolefinyl) ${ }_{2} \mathrm{Zn}$ was treated with $t$-BuLi $([\mathrm{Li}]=2 \times[\mathrm{Zn}]+$ [Al], i.e., 250 or $450 \mu \mathrm{mol}$ ) at $130-135^{\circ} \mathrm{C}$ for $1.0 \mathrm{~h}$ aiming to generate polyolefinyl-Li by destroying the transiently generated $(t \mathrm{Bu})_{2} \mathrm{Zn}$. Among other monomers, styrene $(5.0 \mathrm{~g})$ was fed, aiming to grow a PS chain initiating from polyolefinyl-Li. All the fed styrene monomers were completely converted to polymer in $4 \mathrm{~h}$, but the desired PO-block-PS was not generated. In GPC studies, two signals were observed in opposite directions relative to the base line: A very high molecular weight negative signal $\left(M_{\mathrm{n}} 1150000, M_{\mathrm{w}} / M_{\mathrm{n}} 1.2\right)$ assigned to homo-PS, and a main positive signal assigned to PO; the $M_{\mathrm{n}}$ value of this signal $\left(M_{\mathrm{n}} 61000, M_{\mathrm{w}} / M_{\mathrm{n}} 2.3\right)$ was not increased relative to that of the homo-PO sample taken before feeding styrene $\left(M_{n} 65000, M_{\mathrm{w}} / M_{\mathrm{n}} 2.1\right.$, Figure S3, entry 1 in Table 1$)$. This observation indicated that the isolated polymer was not a block copolymer but a mixture of homo-PO and homo-PS. However, when PMDTA was added alongside the styrene monomer, the high molecular weight homo-PS signal disappeared, and unimodal curves were observed with narrow molecular weight distributions $\left(M_{\mathrm{w}} / M_{\mathrm{n}}\right.$ 1.3-1.5). Moreover, after the styrene polymerization, the GPC curves were shifted to a high molecular weight direction with a significant increase in the $M_{n}$ values $\left(\Delta M_{n} 13-41 \mathrm{kDa}\right)$, indicating the generation of the desired PO-block-PS (Figure S4, entries 2-5).

Table 1. Results for preparation of poly(ethylene-co-propylene)- $b$-PS a

\begin{tabular}{|c|c|c|c|c|c|c|}
\hline Entry & $\begin{array}{l}\text { (1-hexyl })_{2} \mathrm{Zn} \\
\quad(\mu \mathrm{mol})\end{array}$ & $\begin{array}{l}t \text {-BuLi } \\
(\mu \mathrm{mol})\end{array}$ & $\begin{array}{c}\mathrm{PO}(\mathrm{g}) ; F_{\mathrm{C3}} \\
(\mathrm{mol} \%)^{\mathrm{b}}\end{array}$ & $\begin{array}{c}\text { PS }(\mathrm{g}) ; \text { Homo } \\
\text { Fraction }(\%)\end{array}$ & $\begin{array}{c}M_{\mathrm{n}}(\mathrm{kDa}) ; \text { PDI } \\
\text { before Styrene } \\
\text { Polym }^{\mathrm{c}}\end{array}$ & $\begin{array}{c}M_{\mathrm{n}}(\mathrm{kDa}) ; \text { PDI } \\
\text { after Styrene } \\
\text { Polym }{ }^{\mathrm{c}}\end{array}$ \\
\hline $1^{d}$ & 100 & 250 & $13.1 ; 23.4$ & 5.0 ; - & $64.6(2.10)$ & $61.3(2.30)$ \\
\hline 2 & 100 & 250 & $11.4 ; 20.5$ & $5.0 ; 21$ & $108(1.48)$ & $121(1.48)$ \\
\hline 3 & 100 & 250 & $12.5 ; 22.6$ & $10 ; 27$ & $92(1.62)$ & $111(1.54)$ \\
\hline 4 & 200 & 450 & $12.9 ; 22.4$ & $5.0 ; 28$ & $51(1.66)$ & 75 (1.33) \\
\hline 5 & 200 & 450 & $15.2 ; 22.8$ & $10 ; 30$ & 48 (1.74) & 89 (1.28) \\
\hline $\begin{array}{l}\text { a } \\
\text { ano } \\
\text { and } \\
\text { [PI } \\
\text { calc } \\
\text { tricl } \\
\text { of } P\end{array}$ & $\begin{array}{l}\text { erization } \mathrm{cc} \\
\text { methylalumi } \\
-\mathrm{BuLi} \text { and sty } \\
=[\mathrm{Li}]) \text { for } \\
\text { from }{ }^{1} \mathrm{H} \mathrm{NI} \\
\text { enzene relati }\end{array}$ & $\begin{array}{l}\text { tions: } \\
\text { ne) as } \\
\text { ( } 5 \text { or } 1\end{array}$ & \multicolumn{4}{|c|}{$\begin{array}{l}\text { methylcyclohexane }(26 \mathrm{~g}), \quad \text { catalyst }(2.0 \mu \mathrm{mol}), \text { and } \mathrm{MMAO} \\
\text { avenger }(50 \mu \mathrm{mol}-\mathrm{Al}) \text { for coordinative chain transfer polymerization (CCTP) } \\
\text { in methylcyclohexane }(15 \mathrm{~g}) \text { and pentamethyldiethylenetriamine (PMDTA) } \\
\text { erization. b Propylene content in poly(ethylene-co-propylene) block was } \\
\text { Measured with gel permeation chromatography (GPC) at } 160{ }^{\circ} \mathrm{C} \text { using } \\
\text { ne (PS) standards. }{ }^{d} \text { Styrene polymerization was performed in the absence }\end{array}$} \\
\hline
\end{tabular}

Attempts to grow other polymer chains (e.g., polyisoprene and polycaprolactone) initiating from polyolefinyl-Li, which was assumed to be generated, were unsuccessful. After performing anion polymerization of isoprene, the GPC curves were not shifted to a high molecular weight direction, i.e., the $M_{\mathrm{n}}$ values increased negligibly. We eventually found that $t$-BuLi reacted with olefin monomers; hence, we attempted to convert the CCTP product (polyolefinyl) ${ }_{2} \mathrm{Zn}$ to polyolefinyl-Li by thoroughly flushing ethylene/propylene residual gases before adding $t$-BuLi. However, many attempts were also unsuccessful. Either the low concentration of $\mathrm{Zn}$ species relative to that in the (1-octyl) ${ }_{2} \mathrm{Zn}$ model studies or the difficulty of the formation of aggregates, in the case of polyolefinyl-Li, might have caused the failure in converting (polyolefinyl) ${ }_{2} \mathrm{Zn}$ to polyolefinyl-Li.

\subsection{Initiators for PS Chain Growth from Dialkylzinc}

PO-block-PSs were efficiently generated when the CCTP product (polyolefinyl) ${ }_{2} \mathrm{Zn}$ was treated with $t$-BuLi and PMDTA in the presence of residual propylene gas. We assumed that allyl-Li.(PMDTA), generated from the reaction of $t$-BuLi, propylene and PMDTA, might work as an efficient initiator to grow PS chains from (polyolefinyl) ${ }_{2} \mathrm{Zn}$ (Scheme 3). Therefore, we prepared a reaction of 1-octene with $n$-BuLi in methylcyclohexane in the presence of PMDTA. After overnight stirring, $n$-BuLi signals completely disappeared from the ${ }^{1} \mathrm{H}$ NMR spectrum, and the resulting solution was used as an initiator for styrene polymerization in the presence of (1-hexyl) ${ }_{2} \mathrm{Zn}$ (entries 1-3 in Table 2). The number of PS chains was calculated by dividing the isolated PS weight by the measured $M_{n}$ value. The obtained PS 
chains were twofold the fed Zn amount $(205,203$, and $203 \mu \mathrm{mol}$ vs. $2 \times 100=200 \mu \mathrm{mol})$, and their numbers were unaltered by the amount of the fed lithium species (50, 70, and $100 \mu \mathrm{mol}$, respectively). These observations indicated that the PS chains were grown selectively from all the fed (1-hexyl ${ }_{2} \mathrm{Zn}$ and that the lithium species worked only as an activator in the PS chain-growth process, not directly engaging as a PS chain-growing site. One disadvantage was that the styrene monomers were not completely converted to polymer, affording a $92-96 \%$ yield, even considering the long reaction time of $5 \mathrm{~h}$ at a high temperature of $90{ }^{\circ} \mathrm{C}$. The molecular weight distributions were rather broad $\left(M_{\mathrm{W}} / M_{\mathrm{n}}\right.$, $1.35-1.45)$.

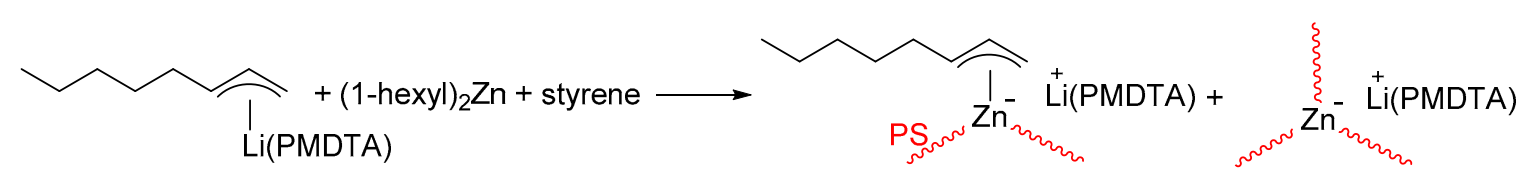

Scheme 3. PS chain-growth process from dialkylzinc.

Table 2. Results of anionic styrene polymerization in the presence of (1-hexyl $)_{2} \mathrm{Zn}(100 \mu \mathrm{mol})^{\mathrm{a}}$.

\begin{tabular}{|c|c|c|c|c|c|c|}
\hline Entry & Initiator & $\mathrm{Li}(\mu \mathrm{mol})$ & yield $(g ; \%)$ & $M_{\mathrm{n}}(\mathrm{Da})^{b}$ & $M_{\mathrm{w}} / M_{\mathrm{n}}$ & $\begin{array}{c}\# \text { of PS chains } \\
(\mu \mathrm{mol})^{c}\end{array}$ \\
\hline 1 & 1-octene $+n$-BuLi + PMDTA in MeCy & 50 & $4.69 ; 94$ & 22,900 & 1.45 & 205 \\
\hline 2 & 1-octene $+n$-BuLi + PMDTA in MeCy & 70 & $4.62 ; 92$ & 22,800 & 1.39 & 203 \\
\hline 3 & 1-octene $+n$-BuLi + PMDTA in MeCy & 100 & $4.82 ; 96$ & 23,800 & 1.35 & 203 \\
\hline 4 & $\mathrm{Me}_{2} \mathrm{NCH}_{2} \mathrm{CH}_{2} \mathrm{~N}(\mathrm{Me}) \mathrm{CH}_{2} \mathrm{CH}_{2} \mathrm{~N}(\mathrm{Me}) \mathrm{CH}_{2} \mathrm{Li}$ & 100 & $4.75 ; 95$ & 19,700 & 1.25 & 240 \\
\hline 5 & $\mathrm{Me}_{2} \mathrm{NCH}_{2} \mathrm{CH}_{2} \mathrm{~N}(\mathrm{Me}) \mathrm{Li}$ & 100 & $1.14 ; 23$ & 7400 & 2.10 & 154 \\
\hline 6 & $\mathrm{Me}_{2} \mathrm{NCH}_{2} \mathrm{CH}_{2} \mathrm{~N}(\mathrm{Me}) \mathrm{Li} \cdot(\mathrm{PMDTA})$ & 50 & $4.56 ; 91$ & 21,000 & 1.32 & 217 \\
\hline 7 & $\mathrm{Me}_{2} \mathrm{NCH}_{2} \mathrm{CH}_{2} \mathrm{~N}(\mathrm{Me}) \mathrm{Li} \cdot(\mathrm{PMDTA})$ & 70 & $4.63 ; 93$ & 22,300 & 1.33 & 208 \\
\hline 8 & $\mathrm{Me}_{2} \mathrm{NCH}_{2} \mathrm{CH}_{2} \mathrm{~N}(\mathrm{Me}) \mathrm{Li} \cdot(\mathrm{PMDTA})$ & 100 & $4.67 ; 93$ & 24,000 & 1.27 & 195 \\
\hline 9 & pentylallyl-Li·(PMDTA) & 50 & $5.00 ; 100$ & 21,500 & 1.28 & 233 \\
\hline 10 & pentylallyl-Li·(PMDTA) & 70 & $5.00 ; 100$ & 20,800 & 1.24 & 240 \\
\hline 11 & pentylallyl-Li·(PMDTA) & 100 & $5.00 ; 100$ & 19,400 & 1.30 & 258 \\
\hline 12 & PhLi·(PMDTA) & 50 & $5.00 ; 100$ & 22,000 & 1.30 & 227 \\
\hline 13 & PhLi·(PMDTA) & 70 & $4.98 ; 99$ & 21,100 & 1.27 & 236 \\
\hline 14 & PhLi·(PMDTA) & 100 & $4.98 ; 99$ & 21,000 & 1.24 & 237 \\
\hline 15 & $n$-BuLi·(PMDTA) & 100 & $4.96 ; 99$ & 21,000 & 1.48 & 236 \\
\hline 16 & $\mathrm{Me}_{3} \mathrm{SiCH}_{2} \mathrm{Li} \cdot(\mathrm{PMDTA})$ & 100 & $5.00 ; 100$ & 23,000 & 1.25 & 217 \\
\hline
\end{tabular}

${ }^{a}$ Polymerization conditions: (1-hexyl) ${ }_{2} \mathrm{Zn}(22.6 \mathrm{mg}, 100 \mu \mathrm{mol})$, methylcyclohexane $(27 \mathrm{~g})$, styrene $(5.0 \mathrm{~g}, 48 \mathrm{mmol})$, $90{ }^{\circ} \mathrm{C}, 5$ h. ${ }^{\mathrm{b}}$ Measured by GPC at $40{ }^{\circ} \mathrm{C}$ using toluene eluent. ${ }^{\mathrm{c}}$ Calculated as yield $(\mathrm{g}) / \mathrm{M}_{\mathrm{n}}$.

We observed broad and unassignable signals in the ${ }^{1} \mathrm{H}$ NMR spectrum of the lithium species generated in the reaction pot of "1-octene + $n$-BuLi + PMDTA" in methylcylohexane (Figure S5). However, the spectra recorded after quenching with $\mathrm{H}_{2} \mathrm{O}$ and $\mathrm{D}_{2} \mathrm{O}$, indicated the presence of pentylallyl- $\mathrm{Li}, \mathrm{Me}_{2} \mathrm{NCH}_{2} \mathrm{CH}_{2} \mathrm{~N}(\mathrm{Me}) \mathrm{Li}$, and $\mathrm{Me}_{2} \mathrm{NCH}_{2} \mathrm{CH}_{2} \mathrm{~N}(\mathrm{Me}) \mathrm{CH}_{2} \mathrm{CH}_{2} \mathrm{~N}(\mathrm{Me}) \mathrm{CH}_{2} \mathrm{Li}$ (Figure S6). The reaction of $n$-BuLi with PMDTA in $\mathrm{C}_{6} \mathrm{D}_{12}$ was monitored with ${ }^{1} \mathrm{H}$ NMR spectroscopy, which revealed that $n$-BuLi reacted with PMDTA slowly, requiring $\sim 8 \mathrm{~h}$ at room temperature for the complete consumption of $n$ - $\mathrm{BuLi}$, to generate mainly $\mathrm{Me}_{2} \mathrm{NCH}_{2} \mathrm{CH}_{2} \mathrm{~N}(\mathrm{Me}) \mathrm{CH}_{2} \mathrm{CH}_{2} \mathrm{~N}(\mathrm{Me}) \mathrm{CH}_{2} \mathrm{Li}$ (Figure S7) [50,51]. The generated $\mathrm{Me}_{2} \mathrm{NCH}_{2} \mathrm{CH}_{2} \mathrm{~N}(\mathrm{Me}) \mathrm{CH}_{2} \mathrm{CH}_{2} \mathrm{~N}(\mathrm{Me}) \mathrm{CH}_{2} \mathrm{Li}$ was unstable; thus, it converted to $\mathrm{Me}_{2} \mathrm{NCH}_{2} \mathrm{CH}_{2} \mathrm{~N}(\mathrm{Me}) \mathrm{Li}, \mathrm{Me}_{2} \mathrm{NLi}$, and PMDTA [45]. sec-BuLi reacted with PMDTA within 30 min at room temperature, to generate mainly $\mathrm{Me}_{2} \mathrm{NCH}_{2} \mathrm{CH}_{2} \mathrm{~N}(\mathrm{Me}) \mathrm{CH}_{2} \mathrm{CH}_{2} \mathrm{~N}(\mathrm{Me}) \mathrm{CH}_{2} \mathrm{Li}$ in $\mathrm{C}_{6} \mathrm{D}_{12}$ (Figure S8) [52]. PMDTA treated with $n$-BuLi in $\mathrm{C}_{6} \mathrm{D}_{6}$ cleanly afforded $\mathrm{C}_{6} \mathrm{D}_{5} \mathrm{Li}$.(PMDTA) (Figure S9). When PMDTA was mixed with $n$-BuLi in 1-octene (as a solvent as well as a reactant), the color of the solution slowly turned to yellow. The ${ }^{1} \mathrm{H}$ NMR spectrum of the lithium species

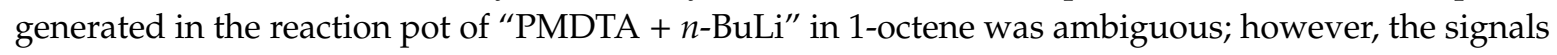
assigned to 2-octene (as a mixture of cis- and trans-isomers) and 1-octene were observed after quenching with $\mathrm{H}_{2} \mathrm{O}$, indicating the generation of pentylallyl-Li species in the reaction pot of "PMDTA $+n$-BuLi" in 1-octene (Figure S10). 
Upon these observations, organolithium species that might be generated by the reaction of $\mathrm{BuLi}$, olefin, and PMDTA, were screened as initiators for styrene polymerization in the presence of (1-hexyl) ${ }_{2} \mathrm{Zn}$ (Table 2). Organolithium species generated in situ or prepared were fed in the polymerization pot containing styrene $(5.0 \mathrm{~g})$ and $(1-\mathrm{hexyl})_{2} \mathrm{Zn}(100 \mu \mathrm{mol})$ in methylcyclohexane and polymerization was performed at $90^{\circ} \mathrm{C}$ for $5 \mathrm{~h}$. The numbers of PS chain-growing sites were calculated by dividing the isolated PS weights by the measured $M_{n}$ values, which were monitored to see whether PS chains were well-grown from (1-hexyl) $2 \mathrm{Zn}$. When $\mathrm{Me}_{2} \mathrm{NCH}_{2} \mathrm{CH}_{2} \mathrm{~N}(\mathrm{Me}) \mathrm{CH}_{2} \mathrm{CH}_{2} \mathrm{~N}(\mathrm{Me}) \mathrm{CH}_{2} \mathrm{Li}$ $(100 \mu \mathrm{mol})$ was generated, in situ, in the reaction pot of "sec-BuLi + PMDTA in methylcyclohexane" in 30 min was used (entry 4), styrene monomers were not completely converted to PS (95\% yield) and the calculated number of PS chain-growing sites was $240 \mu$ mol, exceeding the value of " $2 \times \mathrm{Zn}(\mu \mathrm{mol})$ ", but not surpassing the value of " $2 \times \mathrm{Zn}(\mu \mathrm{mol})+\mathrm{Li}(\mu \mathrm{mol})$ ". The molecular weight distribution was narrow $\left(M_{\mathrm{w}} / M_{\mathrm{n}}, 1.25\right)$. When $\mathrm{Me}_{2} \mathrm{NCH}_{2} \mathrm{CH}_{2} \mathrm{~N}(\mathrm{Me}) \mathrm{Li}$ was used (entry 5), styrene conversion was unsatisfactorily low (23\%). However, when $\mathrm{Me}_{2} \mathrm{NCH}_{2} \mathrm{CH}_{2} \mathrm{~N}(\mathrm{Me}) \mathrm{Li}$.(PMDTA) was used instead (entries 6-8), the conversions were high but not quantitative (91-93\%). The calculated number of PS chains agreed well with the value of " $2 \times \mathrm{Zn}$ ( $\mu \mathrm{mol})$ " (217, 208, and $195 \mu \mathrm{mol}$ versus $2 \times 100 \mu \mathrm{mol})$ and it was almost unaffected by the increase in the feed amount of lithium species $(50,70$, and $100 \mu \mathrm{mol}$, respectively), which indicated that the PS chains were grown selectively from all the fed Zn species, and not from $\mathrm{Me}_{2} \mathrm{NCH}_{2} \mathrm{CH}_{2} \mathrm{~N}(\mathrm{Me}) \mathrm{Li}$.

When pentylallyl-Li.(PMDTA) generated in situ in the reaction pot of " $n$-BuLi + PMDTA" in 1-octene was used (entries 9-11), styrene monomers were completely converted to PS, and the number of PS chain-growing sites exceeded the value of " $2 \times \mathrm{Zn}(\mu \mathrm{mol})$ " (233, 240, and $258 \mu \mathrm{mol}$, respectively) and it increased with the increase in the feed amount of lithium species (50, 70, and $100 \mu \mathrm{mol}$, respectively). These observations indicated that PS chains were grown from all the $\mathrm{Zn}$ sites, as well as from some portion of the fed organolithium species (Scheme 3). PhLi.(PMDTA) showed similar results with pentylallyl-Li, which exhibited performance comparable to that of $\mathrm{Me}_{3} \mathrm{SiCH}_{2} \mathrm{Li}$.(PMDTA) and n-BuLi.(PMDTA) - previously introduced as initiators in growing PS chains from dialkylzinc (entries 15 and 16) $[33,45]$. Styrene monomers were quantitatively converted to PS and the numbers of PS chains were comparable, exceeding the value of " $2 \times \mathrm{Zn}(\mu \mathrm{mol})$ " (220-260 $\mu \mathrm{mol})$, in all cases. The molecular weight distributions in the cases of pentylallyl-Li.(PMDTA), $\mathrm{PhLi}$ (PMDTA), and $\mathrm{Me}_{3} \mathrm{SiCH} \mathrm{CH}_{2} \mathrm{Li}$.(PMDTA) were narrow $\left(M_{\mathrm{W}} / M_{\mathrm{n}}\right.$ 1.24-1.30), while the distribution in the case of $n$-BuLi.(PMDTA) was rather broad $\left(M_{\mathrm{w}} / M_{\mathrm{n}} 1.48\right)$.

\subsection{Synthesis of PO-Block-PS}

CCTcoPs were performed with (1-hexyl) ${ }_{2} \mathrm{Zn}(150$ or $300 \mu \mathrm{mol})$ as CTA using $\mathbf{1}$ as a catalyst by feeding an ethylene/propylene mixed gas to generate (polyolefinyl) ${ }_{2} \mathrm{Zn}$. After CCTcoP, lithium species $([\mathrm{Li}]=[\mathrm{Zn}]+[\mathrm{Al}]$, i.e., 450 or $650 \mu \mathrm{mol})$ and styrene monomers $(5.0$ or $10 \mathrm{~g})$ were sequentially fed and styrene polymerization was performed for $4 \mathrm{~h}$, at a reasonably high temperature of $90-100^{\circ} \mathrm{C}$ to prevent precipitation of the generated polymers. Running the styrene polymerization at higher temperature up to $120{ }^{\circ} \mathrm{C}$ was not problematic. At the initial stage of the styrene polymerization, a clear yellowish solution was developed, which became turbid for approximately $5 \mathrm{~min}$, and eventually turned back to a clear yellowish viscous solution once the block copolymers were well-generated. When the block copolymers were not generated well (e.g., entry 1 in Table 1 and entry 3 in Table 3), the polymerization solution was turbid throughout the styrene polymerization. The isolated PO-block-PS polymers were transparent, while mixtures of homo-PO and homo-PS were opaquely white. 
Table 3. Results for preparation of poly(ethylene-co-propylene)- $b$-PS ${ }^{a}$.

\begin{tabular}{|c|c|c|c|c|c|c|c|}
\hline Entry & $\begin{array}{c}(\text { hexyl })_{2} \mathrm{Zn} \\
(\mu \mathrm{mol})\end{array}$ & Initiator & $\begin{array}{c}\mathrm{PO}(\mathrm{g}) ; F_{\mathrm{C} 3} \\
(\mathrm{~mol} \%)^{\mathrm{b}}\end{array}$ & $\begin{array}{c}\text { PS }(\mathrm{g}) ; \text { Homo } \\
\text { Fraction }(\%)\end{array}$ & $\begin{array}{l}\text { Homo-PS } M_{\mathrm{n}} \\
\text { (kDa); PDI }\end{array}$ & $\begin{array}{c}M_{\mathrm{n}}(\mathrm{kDa}) ; \text { PDI } \\
\text { before Styrene } \\
\text { Polym }^{\mathrm{c}}\end{array}$ & $\begin{array}{c}M_{\mathrm{n}}(\mathrm{kDa}) ; \mathrm{PDI} \\
\text { after Styrene } \\
\text { Polym }^{c}\end{array}$ \\
\hline 1 & 150 & 1-octene $+n$-BuLi + PMDTA in MeCy & $15.6 ; 22$ & $5.0 ; 29$ & $24(1.41)$ & $61(1.75)$ & $66(1.64)$ \\
\hline 3 & 150 & $\mathrm{Me}_{2} \mathrm{NCH}_{2} \mathrm{CH}_{2} \mathrm{~N}(\mathrm{Me}) \mathrm{Li} \cdot(\mathrm{PMDTA})$ & $15.9 ; 23$ & $3.5 ; 30$ & $39(2.77)$ & $60(1.76)$ & $64(1.70)$ \\
\hline 4 & 150 & pentylallyl-Li.(PMDTA) & $13.1 ; 17$ & $5.0 ; 29$ & $16(1.25)$ & $60(1.61)$ & $82(1.39)$ \\
\hline 5 & 150 & pentylallyl-Li·(PMDTA) & $13.5 ; 21$ & $10 ; 28$ & $27(1.24)$ & $62(1.61)$ & $99(1.30)$ \\
\hline 6 & 300 & pentylallyl-Li.(PMDTA) & $14.2 ; 22$ & $5.0 ; 27$ & $11(1.23)$ & $40(1.50)$ & $51(1.35)$ \\
\hline 9 & 150 & PhLi·(PMDTA) & $13.0 ; 17$ & $10 ; 34$ & $28(1.39)$ & $67(1.63)$ & $105(1.29)$ \\
\hline 10 & 300 & PhLi·(PMDTA) & $12.0 ; 22$ & $5.0 ; 30$ & $11(1.40)$ & $33(1.58)$ & $43(1.41)$ \\
\hline 11 & 300 & PhLi·(PMDTA) & $14.8 ; 23$ & $10 ; 33$ & $16(1.38)$ & $38(1.64)$ & $59(1.34)$ \\
\hline 12 & 150 & $n$-BuLi.(PMDTÁ) & $14.6 ; 24$ & $5.0 ; 45$ & $23(1.33)$ & $63(1.73)$ & $71(1.65)$ \\
\hline 13 & 150 & $\mathrm{Me}_{3} \mathrm{SiCH}_{2} \mathrm{Li} \cdot(\mathrm{PMDTA})$ & $16.0 ; 21$ & $5.0 ; 27$ & $19(1.35)$ & $71(1.59)$ & $76(1.49)$ \\
\hline
\end{tabular}

a Polymerization conditions: methylcyclohexane $(26 \mathrm{~g})$, catalyst $(2.0 \mu \mathrm{mol})$, and MMAO (50 $\mu \mathrm{mol}-\mathrm{Al})$ as a scavenger for CCTP and then lithium compound ([Li] = [Zn] + [Al]) and styrene $(5.0 \mathrm{~g}$ or $10 \mathrm{~g})$ in methylcyclohexane $(15 \mathrm{~g})$ for anionic polymerization. ${ }^{b}$ Propylene content in poly(ethylene-co-propylene) block was calculated from ${ }^{1} \mathrm{H}$ NMR spectra. ${ }^{\mathrm{C}}$ Measured by GPC at $160^{\circ} \mathrm{C}$ using trichlorobenzene relative to PS standards.

When the lithium species generated in the reaction pot of "1-octene $+n-\mathrm{BuLi}+\mathrm{PMDTA}^{\text {" in }}$ methylcyclohexane was used as an initiator, the styrene monomers were completely converted to polymer. However, the increase in the molecular weight was marginal after the styrene polymerization $\left(\Delta M_{\mathrm{n}} 5 \mathrm{kDa}\right.$, entry 1 in Table 3). The molecular weight distribution was also marginally narrowed from an $M_{\mathrm{w}} / M_{\mathrm{n}}$ value of 1.75 to 1.64 after the styrene polymerization. When $\mathrm{Me}_{2} \mathrm{NCH}_{2} \mathrm{CH}_{2} \mathrm{~N}(\mathrm{Me}) \mathrm{CH}_{2} \mathrm{CH}_{2} \mathrm{~N}(\mathrm{Me}) \mathrm{CH}_{2} \mathrm{Li}$ generated in the reaction pot of "sec-BuLi + PMDTA" in methylcyclohexane was used, the styrene polymerization was not initiated at all. When $\mathrm{Me}_{2} \mathrm{NCH}_{2} \mathrm{CH}_{2} \mathrm{~N}(\mathrm{Me}) \mathrm{Li}$.(PMDTA) was used, the styrene monomers were partially converted to PS ( $60 \%$ conversion, entry 3$)$.

Pentylallyl-Li.(PMDTA) generated in the reaction pot of " $n$-BuLi + PMDTA" in 1-octene was the best initiator. The GPC curves were shifted to a high molecular weight direction after the styrene polymerization (Figure 2 and Figure S11). Increases in the $M_{\mathrm{n}}$ values, after styrene polymerization, were substantial and reasonable $\left(\Delta M_{\mathrm{n}} 22,37,11,20 \mathrm{kDa}\right.$, entries 4-7). By feeding the amount of styrene monomers twice under otherwise identical conditions, the $\Delta M_{\mathrm{n}}$ values almost doubled from $22 \mathrm{kDa}$ to $37 \mathrm{kDa}$ and from $11 \mathrm{kDa}$ to $20 \mathrm{kDa}$. By feeding twice the amount of $\mathrm{Zn}$ species in CCTcoP and accordingly twice the amount of lithium species under otherwise identical conditions, the $\Delta M_{\mathrm{n}}$ values were reduced almost by half from $22 \mathrm{kDa}$ to $11 \mathrm{kDa}$ and from $37 \mathrm{kDa}$ to $20 \mathrm{kDa}$. The molecular weight distributions were also substantially narrowed after the styrene polymerization from the $M_{\mathrm{w}} / M_{\mathrm{n}}$ values of $1.61,1.61,1.50$, and 1.54 , to $1.39,1.30,1.35$, and 1.26 , respectively ( $\triangle \mathrm{PDI} 0.22,0.31,0.15$, and 0.28 ). A weak melting $\left(T_{\mathrm{m}}\right)$ signal corresponding to poly(ethylene-co-propylene) block and a glass transition $\left(T_{\mathrm{g}}\right)$ signal corresponding to PS block were independently observed at a broad range of $30-80{ }^{\circ} \mathrm{C}$ and $\sim 100{ }^{\circ} \mathrm{C}$, respectively, on differential scanning calorimetry (DSC) (Figure S12).
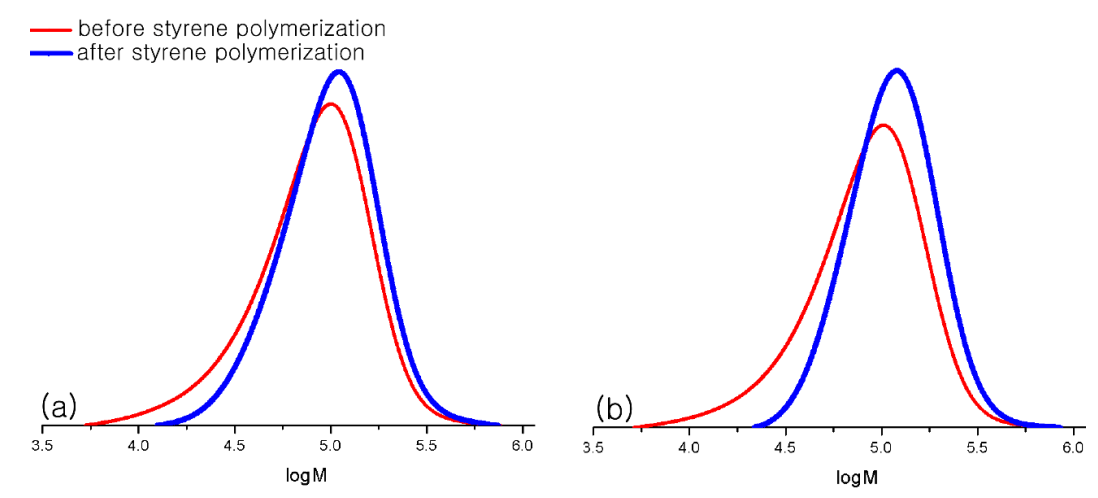

Figure 2. GPC curves of the polymers before and after styrene polymerization: (a) entry 4; (b) entry 5 in Table 2. 
Homo-PS could be separated from the block copolymers by extraction with an acetone/chloroform mixed solvent. The extracted homo-PS was $~ 1 / 3(27-29 \%)$ of the amount of the total consumed styrene, from which we hypothesized that the PS chains were grown from both polyolefinyl and pentylallyl groups in the zincate species [(polyolefinyl $)_{2}$ (pentylallyl)Zn] $]^{-}[\mathrm{Li} \cdot(\mathrm{PMDTA})]^{+}$formed by the action of pentylallyl-Li.(PMDTA) onto (polyolefinyl) ${ }_{2} Z n$; PS chain growth from polyolefinyl groups results in the generation of the desired poly(ethylene-co-propylene)-block-PS, while that from pentylallyl generates homo-PS in $1 / 3$ of the total consumed styrene. However, the number of the PS chain-growing sites calculated by dividing the weights of the total consumed styrene by the measured homo-PS $M_{\mathrm{n}}$ values, did not match the value of " $3 \times \mathrm{Zn}(\mu \mathrm{mol})$ ", opposing the hypothesis. Conversely, that number agreed with the value of " $2 \times \mathrm{Zn}(\mu \mathrm{mol})$ " (310 and $360 \mu \mathrm{mol}$ vs. $2 \times 150=300 \mu \mathrm{mol}$ for entries 4 and 5; $630 \mu \mathrm{mol}$ vs. $2 \times 300=600 \mu \mathrm{mol}$ for entry 7). Thus, we hypothesized that the PS chains were grown mainly from polyolefinyl groups in the formed zincate species [(polyolefinyl $)_{2}$ (pentylallyl)Zn $]^{-}[\mathrm{Li} \cdot(\mathrm{PMDTA})]^{+}$ (Scheme 4); we attributed the extracted homo-PS to the PS chains grown either from the 1-hexyl group, which may remain intact during CCTP or from the polyolefinyl groups, which are grown shortly in CCTP. When the feed amount of $\mathrm{Zn}$ species was high $(300 \mu \mathrm{mol})$ and the feed amount of styrene monomers was too low (5.0 g) (entry 6), the number of PS chain-growing sites did not exceed the value of " $2 \times \mathrm{Zn}(\mu \mathrm{mol})$ " (450 $\mu \mathrm{mol}$ vs. $2 \times 300=600 \mu \mathrm{mol})$, which indicated that the PS chains were not grown from all the polyolefinyl-Zn groups. The molecular weight distributions of the extracted homo-PS were fairly narrow $\left(M_{\mathrm{w}} / M_{\mathrm{n}} 1.23-1.25\right)$, indicating that the anionic styrene polymerization was well-controlled.

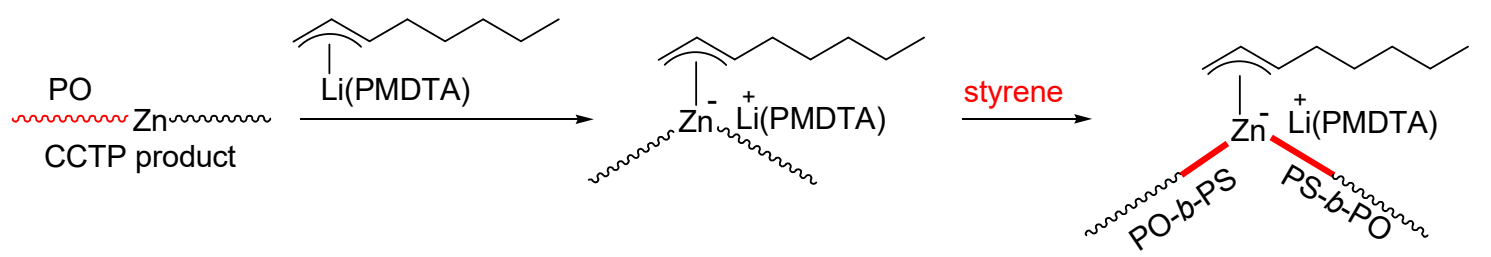

Scheme 4. Synthetic scheme for PO-block-PS.

PhLi·(PMDTA) was as effective an initiator as pentylallyl-Li.(PMDTA) for growing PS chains from (polyolefinyl) ${ }_{2} Z n$. Increases of the $M_{\mathrm{n}}$ values after the styrene polymerization were substantial $\left(\Delta M_{\mathrm{n}}\right.$ $12,38,10,21 \mathrm{kDa}$, entries 8-11; Figure S11), and the molecular weight distributions were significantly narrowed after the styrene polymerization, with the $M_{\mathrm{w}} / M_{\mathrm{n}}$ values going from $1.65,1.63,1.58$, and 1.64 to $1.49,1.29,1.41$, and 1.34, respectively. However, the amounts of the extracted homo-PSs were slightly higher (30-34\% vs. $27-29 \%$ ) and the molecular weight distributions of the extracted homo-PSs were broader than those in the case of pentylallyl-Li.(PMDTA) $\left(M_{\mathrm{w}} / M_{\mathrm{n}} 1.38-1.52\right.$ vs. $\left.1.23-1.25\right)$, indicating that pentylallyl-Li.(PMDTA) might be a better initiator than PhLi.(PMDTA) in growing PS chains from (polyolefinyl) ${ }_{2} \mathrm{Zn}$. Previously, we introduced $n$-BuLi.(TMEDA) and $\mathrm{Me}_{3} \mathrm{SiCH}_{2} \mathrm{Li}$ (PMDTA) as initiators for growing PS chains from the CCTP product (polyolefinyl) ${ }_{2} \mathrm{Zn}$, mainly based on the model studies performed with $\mathrm{R}_{2} \mathrm{Zn}(\mathrm{R}=\mathrm{Et}$, 1-hexyl, benzyl) [32,33]. Though significant performance differences could not be observed among pentylallyl-Li.(PMDTA), PhLi.(PMDTA), n-BuLi.(TMEDA), and $\mathrm{Me}_{3} \mathrm{SiCH}_{2} \mathrm{Li}$.(PMDTA) in the model studies performed with (1-hexyl) ${ }_{2} \mathrm{Zn}$ (Table 2), the studies performed with actual (polyolefinyl) ${ }_{2} \mathrm{Zn}$ indicated that pentylallyl-Li.(PMDTA) and PhLi.(PMDTA) were superior to the previous initiators. When $n$-BuLi.(PMDTA) was used, a substantial amount of homo-PS was generated (45\%, entry 12). When $\mathrm{Me}_{3} \mathrm{SiCH}_{2} \mathrm{Li}$.(PMDTA) was used, the increase in the $M_{\mathrm{n}}$ value after performing the styrene polymerization was not as substantial as that observed for pentylallyl-Li.(PMDTA) or PhLi.(PMDTA) (entry 13).

\section{Conclusions}

Developing a versatile synthetic tool for polyolefin-base block copolymers, we unsuccessfully attempted to convert the CCTP product (polyolefinyl) ${ }_{2} \mathrm{Zn}$ to polyolefinyl-Li though 1-octyl-Li 
was efficiently synthesized from (1-octyl) $)_{2} \mathrm{Zn}$ (a model compound of (polyolefinyl $)_{2} \mathrm{Zn}$ ). However, an efficient initiator to grow PS chains from (polyolefinyl) ${ }_{2} \mathrm{Zn}$ was eventually found. Pentylallyl-Li.(PMDTA) (generated in a pot containing $n$-BuLi and PMDTA in 1-octene) and styrene monomers were added to a reactor containing (polyolefinyl) ${ }_{2} \mathrm{Zn}$ generated via CCTcoP, affording the desired poly(ethylene-co-propylene)-block-PSs. The $\mathrm{M}_{\mathrm{n}}$ values increased substantially after the styrene polymerization, and the increments (i.e., $\Delta M_{n}$ values) were reasonable. By feeding twice the amount of styrene, the increments doubled and, by feeding twice the amount of $\mathrm{Zn}$ species in CCTcoP, and accordingly, twice the amount of lithium species in styrene polymerization, the increments were reduced by half. Homo-PS was concomitantly generated at $27-29 \%$ the amount of the total consumed styrene. The numbers of PS chain-growing sites were calculated by dividing the weights of the total consumed styrene with the measured homo-PS $M_{n}$ values, which roughly agreed with the value of " $2 \times \mathrm{Zn}(\mu \mathrm{mol})$ ", indicating the growth of PS chains mainly from polyolefinyl groups in zincate species [(polyolefinyl) ${ }_{2}$ (pentylallyl)Zn] $]^{-}[\mathrm{Li} \cdot(\mathrm{PMDTA})]^{+}$formed by the action of pentylallyl-Li.(PMDTA) onto (polyolefinyl) ${ }_{2} \mathrm{Zn}$. Pentylallyl-Li.(PMDTA) was superior to $n$-BuLi.(PMDTA) and $\mathrm{Me}_{3} \mathrm{SiCH}_{2} \mathrm{Li}$.(PMDTA) - previously introduced as initiators to grow PS chains from (polyolefinyl) ${ }_{2} \mathrm{Zn}$. Thus, pentylallyl-Li.(PMDTA) may be useful in the production of the commercially relevant PS-block-PO-block-PS copolymer [33,34,52].

Supplementary Materials: The following are available online at http://www.mdpi.com/2073-4360/12/3/537/s1, Figure S1: ${ }^{13} \mathrm{C}$ spectrum of 1-octyllithium prepared from (1-octyl $)_{2} \mathrm{Zn}$ in $\mathrm{C}_{6} \mathrm{D}_{6}$, Figure S2: ${ }^{1} \mathrm{H}$ and ${ }^{13} \mathrm{C}$ NMR spectra of 2-ethylhexyllithium prepared from (2-ethylhexyl) ${ }_{2} \mathrm{Zn}$ in $\mathrm{C}_{6} \mathrm{D}_{6}$, Figure S3: GPC curve after styrene polymerization performed with no addition of PMDTA (Entry 1 in Table 1), Figure S4: GPC curves before and after styrene polymerization, Figure S5: ${ }^{1} \mathrm{H}$ NMR spectrum $\left(\mathrm{C}_{6} \mathrm{D}_{6}\right)$ of the lithium species generated in the pot of "1-octene + n-BuLi + PMDTA" in methylcyclohexane, Figure S6: ${ }^{1} \mathrm{H}$ NMR spectrum $\left(\mathrm{C}_{6} \mathrm{D}_{6}\right)$ of the species generated by quenching the reaction pot of "1-octene + n-BuLi + PMDTA" in methylcyclohexane with $\mathrm{H}_{2} \mathrm{O}$ or $\mathrm{D}_{2} \mathrm{O}$, Figure S6: ${ }^{1} \mathrm{H}$ NMR spectrum $\left(\mathrm{C}_{6} \mathrm{D}_{6}\right)$ of the species generated by quenching the reaction pot of "1-octene + n-BuLi + PMDTA" in methylcyclohexane with $\mathrm{H}_{2} \mathrm{O}$ or $\mathrm{D}_{2} \mathrm{O}$, Figure S8: ${ }^{1} \mathrm{H}$ spectrum of "sec-BuLi + PMDTA" in $\mathrm{C}_{6} \mathrm{D}_{12}(30 \mathrm{~min})$, Figure S9: ${ }^{1} \mathrm{H}$ spectrum of $\mathrm{C} 6 \mathrm{D} 5 \mathrm{Li} \times($ PMDTA) prepared in the reaction pot of "n-BuLi + PMDTA" in $\mathrm{C}_{6} \mathrm{D}_{6}$, Figure $\mathrm{S} 10:{ }^{1} \mathrm{H}$ spectrum $\left(\mathrm{C}_{6} \mathrm{D}_{6}\right)$ of the lithium species in the pot of " $\mathrm{n}$-BuLi + PMDTA" in 1-octene, Figure S11: GPC curves before and after styrene polymerization, Figure S12: DSC thermogram of PO-block-PS (Entry 5 in Table 3).

Author Contributions: Conceptualization and design of experiments, B.Y.L. and P.C.L.; coordinative chain transfer polymerization, T.J.K., J.W.B., and H.J.L.; styrene polymerizations, S.H.M. and S.M.B.; NMR studies, K.L.P. and J.C.L. All authors have read and agreed to the published version of the manuscript.

Funding: This work was supported by the Korea CCS R\&D Center (KCRC), grant number 2012-0008935, and by the Priority Research Centers Program, grant number 2019R1A6A1A11051471 funded by the National Research Foundation of Korea (NRF).

Conflicts of Interest: The authors declare no conflict of interest. The funders had no role in the design of the study; in the collection, analyses, or interpretation of data; in the writing of the manuscript, or in the decision to publish the results.

\section{References}

1. Bates, C.M.; Bates, F.S. 50th Anniversary Perspective: Block Polymers-Pure Potential. Macromolecules 2017, 50, 3-22. [CrossRef]

2. Guo, X.; Choi, B.; Feng, A.; Thang, S.H. Polymer Synthesis with More Than One Form of Living Polymerization Method. Macromol. Rapid Commun. 2018, 39. [CrossRef]

3. Polymeropoulos, G.; Zapsas, G.; Ntetsikas, K.; Bilalis, P.; Gnanou, Y.; Hadjichristidis, N. 50th Anniversary Perspective: Polymers with Complex Architectures. Macromolecules 2017, 50, 1253-1290. [CrossRef]

4. Kermagoret, A.; Debuigne, A.; Jérôme, C.; Detrembleur, C. Precision design of ethylene- and polar-monomer-based copolymers by organometallic-mediated radical polymerization. Nat. Chem. 2014, 6, 179-187. [CrossRef] [PubMed]

5. Dommanget, C.; D'Agosto, F.; Monteil, V. Polymerization of Ethylene through Reversible Addition-Fragmentation Chain Transfer (RAFT). Angew. Chem. Int. Ed. 2014, 53, 6683-6686. [CrossRef] [PubMed] 
6. Wolpers, A.; Bergerbit, C.; Ebeling, B.; D’Agosto, F.; Monteil, V. Aromatic Xanthates and Dithiocarbamates for the Polymerization of Ethylene through Reversible Addition-Fragmentation Chain Transfer (RAFT). Angew. Chem. Int. Ed. 2019, 58, 14295-14302. [CrossRef] [PubMed]

7. Goring, P.D.; Morton, C.; Scott, P. End-functional polyolefins for block copolymer synthesis. Dalton Trans. 2019, 48, 3521-3530. [CrossRef] [PubMed]

8. Dong, J.Y.; Chung, T.C. Synthesis of Polyethylene Containing a Terminal p-Methylstyrene Group: Metallocene-Mediated Ethylene Polymerization with a Consecutive Chain Transfer Reaction to p-Methylstyrene and Hydrogen. Macromolecules 2002, 35, 1622-1631. [CrossRef]

9. Chung, T.C.; Dong, J.Y. A Novel Consecutive Chain Transfer Reaction to p-Methylstyrene and Hydrogen during Metallocene-Mediated Olefin Polymerization. J. Am. Chem. Soc. 2001, 123, 4871-4876. [CrossRef]

10. Yan, T.; Walsh, D.J.; Qiu, C.; Guironnet, D. One-Pot Synthesis of Block Copolymers Containing a Polyolefin Block. Macromolecules 2018, 51, 10167-10173. [CrossRef]

11. Kay, C.J.; Goring, P.D.; Burnett, C.A.; Hornby, B.; Lewtas, K.; Morris, S.; Morton, C.; McNally, T.; Theaker, G.W.; Waterson, C.; et al. Polyolefin-Polar Block Copolymers from Versatile New Macromonomers. J. Am. Chem. Soc. 2018, 140, 13921-13934. [CrossRef] [PubMed]

12. Jeon, C.; Kim, D.W.; Chang, S.; Kim, J.G.; Seo, M. Synthesis of Polypropylene via Catalytic Deoxygenation of Poly (methyl acrylate). ACS Macro Lett. 2019, 8, 1172-1178. [CrossRef]

13. Kayser, F.; Fleury, G.; Thongkham, S.; Navarro, C.; Martin-Vaca, B.; Bourissou, D. Microphase Separation of Polybutyrolactone-Based Block Copolymers with Sub-20 nm Domains. Macromolecules 2018, 51, 6534-6541. [CrossRef]

14. Walsh, D.J.; Su, E.; Guironnet, D. Catalytic synthesis of functionalized (polar and non-polar) polyolefin block copolymers. Chem. Sci. 2018, 9, 4703-4707. [CrossRef] [PubMed]

15. Chapman, R.; Melodia, D.; Qu, J.-B.; Stenzel, M.H. Controlled poly (olefin)s via decarboxylation of poly(acrylic acid). Polym. Chem. 2017, 8, 6636-6643. [CrossRef]

16. Higaki, Y.; Suzuki, K.; Kiyoshima, Y.; Toda, T.; Nishiura, M.; Ohta, N.; Masunaga, H.; Hou, Z.; Takahara, A. Molecular Aggregation States and Physical Properties of Syndiotactic Polystyrene/Hydrogenated Polyisoprene Multiblock Copolymers with Crystalline Hard Domain. Macromolecules 2017, 50, 6184-6191. [CrossRef]

17. Hotta, A.; Cochran, E.; Ruokolainen, J.; Khanna, V.; Fredrickson, G.H.; Kramer, E.J.; Shin, Y.-W.; Shimizu, F.; Cherian, A.E.; Hustad, P.D.; et al. Semicrystalline thermoplastic elastomeric polyolefins: Advances through catalyst development and macromolecular design. Proc. Natl. Acad. Sci. USA 2006, 103, 15327-15332. [CrossRef]

18. Eagan, J.M.; Xu, J.; Di Girolamo, R.; Thurber, C.M.; Macosko, C.W.; La Pointe, A.M.; Bates, F.S.; Coates, G.W. Combining polyethylene and polypropylene: Enhanced performance with PE/iPP multiblock polymers. Science 2017, 355, 814-816. [CrossRef]

19. Song, X.; Cao, L.; Tanaka, R.; Shiono, T.; Cai, Z. Optically Transparent Functional Polyolefin Elastomer with Excellent Mechanical and Thermal Properties. ACS Macro Lett. 2019, 8, 299-303. [CrossRef]

20. Valente, A.; Mortreux, A.; Visseaux, M.; Zinck, P. Coordinative chain transfer polymerization. Chem. Rev. 2013, 113, 3836-3857. [CrossRef]

21. van Meurs, M.; Britovsek, G.J.P.; Gibson, V.C.; Cohen, S.A. Polyethylene Chain Growth on Zinc Catalyzed by Olefin Polymerization Catalysts: A Comparative Investigation of Highly Active Catalyst Systems across the Transition Series. J. Am. Chem. Soc. 2005, 127, 9913-9923. [CrossRef] [PubMed]

22. Arriola, D.J.; Carnahan, E.M.; Hustad, P.D.; Kuhlman, R.L.; Wenzel, T.T. Catalytic production of olefin block copolymers via chain shuttling polymerization. Science 2006, 312, 714-719. [CrossRef] [PubMed]

23. Hustad, P.O.; Kuhlman, R.L.; Arriola, D.J.; Carnahan, E.M.; Wenzel, T.T. Continuous production of ethylene-based diblock copolymers using coordinative chain transfer polymerization. Macromolecules 2007, 40, 7061-7064. [CrossRef]

24. Saeb, M.R.; Mohammadi, Y.; Kermaniyan, T.S.; Zinck, P.; Stadler, F.J. Unspoken aspects of chain shuttling reactions: Patterning the molecular landscape of olefin multi-block copolymers. Polymer 2017, 116, 55-75. [CrossRef]

25. Vittoria, A.; Busico, V.; Cannavacciuolo, F.D.; Cipullo, R. Molecular Kinetic Study of "Chain Shuttling" Olefin Copolymerization. ACS Catal. 2018, 8, 5051-5061. [CrossRef] 
26. Kim, S.D.; Kim, T.J.; Kwon, S.J.; Kim, T.H.; Baek, J.W.; Park, H.S.; Lee, H.J.; Lee, B.Y. Peroxide-Mediated Alkyl-Alkyl Coupling of Dialkylzinc: A Useful Tool for Synthesis of ABA-Type Olefin Triblock Copolymers. Macromolecules 2018, 51, 4821-4828. [CrossRef]

27. Chenal, T.; Visseaux, M. Combining Polyethylene CCG and Stereoregular Isoprene Polymerization: First Synthesis of Poly (ethylene)-b-(trans-isoprene) by Neodymium Catalyzed Sequenced Copolymerization. Macromolecules 2012, 45, 5718-5727. [CrossRef]

28. Rutkowski, S.; Zych, A.; Przybysz, M.; Bouyahyi, M.; Sowinski, P.; Koevoets, R.; Haponiuk, J.; Graf, R.; Hansen, M.R.; Jasinska-Walc, L.; et al. Toward Polyethylene-Polyester Block and Graft Copolymers with Tunable Polarity. Macromolecules 2017, 50, 107-122. [CrossRef]

29. Li, T.; Wang, W.J.; Liu, R.; Liang, W.H.; Zhao, G.F.; Li, Z.; Wu, Q.; Zhu, F.M. Double-Crystalline Polyethylene-b-poly (ethylene oxide) with a Linear Polyethylene Block: Synthesis and Confined Crystallization in Self-Assembled Structure Formed from Aqueous Solution. Macromolecules 2009, 42, 3804-3810. [CrossRef]

30. Thomas, T.S.; Hwang, W.; Sita, L.R. End-Group-Functionalized Poly ( $\alpha$-olefinates) as Non-Polar Building Blocks: Self-Assembly of Sugar-Polyolefin Hybrid Conjugates. Angew. Chem. Int. Ed. 2016, 55, 4683-4687. [CrossRef]

31. Ota, Y.; Murayama, T.; Nozaki, K. One-step catalytic asymmetric synthesis of all-syn deoxypropionate motif from propylene: Total synthesis of (2R,4R,6R,8R)-2, 4, 6, 8-tetramethyldecanoic acid. Proc. Natl. Acad. Sci. USA 2016, 113, 2857-2861. [CrossRef]

32. Jeon, J.Y.; Park, S.H.; Kim, D.H.; Park, S.S.; Park, G.H.; Lee, B.Y. Synthesis of polyolefin-block-polystyrene through sequential coordination and anionic polymerizations. J. Polym. Sci. Part A Polym. Chem. 2016, 54, 3110-3118. [CrossRef]

33. Park, S.S.; Kim, C.S.; Kim, S.D.; Kwon, S.J.; Lee, H.M.; Kim, T.H.; Jeon, J.Y.; Lee, B.Y. Biaxial Chain Growth of Polyolefin and Polystyrene from 1, 6-Hexanediylzinc Species for Triblock Copolymers. Macromolecules 2017, 50, 6606-6616. [CrossRef]

34. Kim, C.S.; Park, S.S.; Kim, S.D.; Kwon, S.J.; Baek, J.W.; Lee, B.Y. Polystyrene chain growth from di-end-functional polyolefins for polystyrene-polyolefin-polystyrene block copolymers. Polymers 2017, 9, 481. [CrossRef] [PubMed]

35. Kim, D.H.; Park, S.S.; Park, S.H.; Jeon, J.Y.; Kim, H.B.; Lee, B.Y. Preparation of polystyrene-polyolefin multiblock copolymers by sequential coordination and anionic polymerization. RSC Adv. 2017, 7, 5948-5956. [CrossRef]

36. Keyes, A.; Basbug Alhan, H.E.; Ordonez, E.; Ha, U.; Beezer, D.B.; Dau, H.; Liu, Y.-S.; Tsogtgerel, E.; Jones, G.R.; Harth, E. Olefins and Vinyl Polar Monomers: Bridging the Gap for Next Generation Materials. Angew. Chem. Int. Ed. 2019, 58, 12370-12391. [CrossRef]

37. Tan, C.; Chen, C. Emerging Palladium and Nickel Catalysts for Copolymerization of Olefins with Polar Monomers. Angew. Chem. Int. Ed. 2019, 58, 7192-7200. [CrossRef]

38. Zou, C.; Chen, C. Polar-Functionalized, Crosslinkable, Self-Healing, and Photoresponsive Polyolefins. Angew. Chem. Int. Ed. 2020, 59, 395-402. [CrossRef]

39. Georges, S.; Hashmi, O.H.; Bria, M.; Zinck, P.; Champouret, Y.; Visseaux, M. Efficient One-Pot Synthesis of End-Functionalized trans-Stereoregular Polydiene Macromonomers. Macromolecules 2019, 52, 1210-1219. [CrossRef]

40. Finnegan, R.A.; Kutta, H.W. Organometallic Chemistry. XII.1 The Thermal Decomposition of n-Butyllithium, a Kinetic Study2, 3. J. Org. Chem. 1965, 30, 4138-4144. [CrossRef]

41. Boussie, T.R.; Diamond, G.M.; Goh, C.; Hall, K.A.; LaPointe, A.M.; Leclerc, M.K.; Murphy, V.; Shoemaker, J.A.W.; Turner, H.; Rosen, R.K.; et al. Nonconventional Catalysts for Isotactic Propene Polymerization in Solution Developed by Using High-Throughput-Screening Technologies. Angew. Chem. Int. Ed. 2006, 45, 3278-3283. [CrossRef] [PubMed]

42. Kwon, S.J.; Baek, J.W.; Lee, H.J.; Kim, T.J.; Ryu, J.Y.; Lee, J.; Shin, E.J.; Lee, K.S.; Lee, B.Y. Preparation of Pincer Hafnium Complexes for Olefin Polymerization. Molecules 2019, 24, 1676. [CrossRef] [PubMed]

43. Baek, J.W.; Kwon, S.J.; Lee, H.J.; Kim, T.J.; Ryu, J.Y.; Lee, J.; Shin, E.J.; Lee, K.S.; Lee, B.Y. Preparation of half- and post-metallocene hafnium complexes with tetrahydroquinoline and tetrahydrophenanthroline frameworks for olefin polymerization. Polymers 2019, 11, 1093. [CrossRef] 
44. Rocchigiani, L.; Busico, V.; Pastore, A.; Macchioni, A. Comparative NMR Study on the Reactions of Hf(IV) Organometallic Complexes with Al/Zn Alkyls. Organometallics 2016, 35, 1241-1250. [CrossRef]

45. De Rosa, C.; Di Girolamo, R.; Talarico, G. Expanding the Origin of Stereocontrol in Propene Polymerization Catalysis. ACS Catal. 2016, 6, 3767-3770. [CrossRef]

46. Domski, G.J.; Eagan, J.M.; De Rosa, C.; Di Girolamo, R.; LaPointe, A.M.; Lobkovsky, E.B.; Talarico, G.; Coates, G.W. Combined Experimental and Theoretical Approach for Living and Isoselective Propylene Polymerization. ACS Catal. 2017, 7, 6930-6937. [CrossRef]

47. Frazier, K.A.; Froese, R.D.; He, Y.; Klosin, J.; Theriault, C.N.; Vosejpka, P.C.; Zhou, Z.; Abboud, K.A. Pyridylamido hafnium and zirconium complexes: Synthesis, dynamic behavior, and ethylene/1-octene and propylene polymerization reactions. Organometallics 2011, 30, 3318-3329. [CrossRef]

48. Cueny, E.S.; Landis, C.R. Zinc-Mediated Chain Transfer from Hafnium to Aluminum in the Hafnium-Pyridyl Amido-Catalyzed Polymerization of 1-Octene Revealed by Job Plot Analysis. Organometallics 2019, 38, 926-932. [CrossRef]

49. Lee, H.J.; Baek, J.W.; Kim, T.J.; Park, H.S.; Moon, S.H.; Park, K.L.; Bae, S.M.; Park, J.; Lee, B.Y. Synthesis of Long-Chain Branched Polyolefins by Coordinative Chain Transfer Polymerization. Macromolecules 2019, 52, 9311-9320. [CrossRef]

50. Strohmann, C.; Gessner, V.H. From the Alkyllithium Aggregate [\{(nBuLi $\left.\left.)_{2} \cdot P M D T A\right\}_{2}\right]$ to Lithiated PMDTA. Angew. Chem. Int. Ed. 2007, 46, 4566-4569. [CrossRef]

51. Wang, Y.; Liu, J.; Huang, L.; Zhu, R.; Huang, X.; Moir, R.; Huang, J. KOtBu-Catalyzed lithiation of PMDTA and the direct functionalization of bridged alkenes under mild conditions. Chem. Commun. 2017, 53, 4589-4592. [CrossRef] [PubMed]

52. Luitjes, H.; Schakel, M.; Aarnts, M.P.; Schmitz, R.F.; de Kanter, F.J.J.; Klumpp, G.W. Reactions of the Butyllithiums with Tertiary Oligoethylenepolyamines. Tetrahedron 1997, 53, 9977-9988. [CrossRef]

(C) 2020 by the authors. Licensee MDPI, Basel, Switzerland. This article is an open access article distributed under the terms and conditions of the Creative Commons Attribution (CC BY) license (http://creativecommons.org/licenses/by/4.0/). 